\title{
The Need to Resuscitate the Cultural Rite of Virginity Testing as a Tool to Strengthen the Campaign Against HIVIAIDS and Moral Decadence in South African Region
}

\author{
Prof. S. M Kang'ethe \\ University of Fort Hare, Department of Social Work and Social Development \\ Box X1314, ALICE. 5700, South Africa \\ Email: skangethe@ufh.ac.za
}

\section{Doi:10.5901/mjss.2014.v5n8p484}

\begin{abstract}
The aim of this article is to discus through discourses on the benefits or the panacea of virginity testing as a tool of HIV/AIDS campaign and moral decadence. It has used a review of literature methodology. Findings indicate that virginity can be a homegrown solution to social vices in South African countries; can be an integral component of behavioural change; and can form an important component of the HIV/AIDS campaign. The article advices all the Africans not to take the western world concept of the human rights wholesomely, but must carry out their cost benefit analysis to decide for themselves what works for them. The need to respect cultural rights as an integral component of the continuum of human rights has been emphasized.
\end{abstract}

Keywords: Panacea of cultures, sexual mores and taboos, integration of cultures, cultural Heritage, cultural legacy

\section{Problem Statement}

Since African countries are slowly realizing the lost glory embedded in their cultures that they lost during the period of colonialization and in South Africa apartheid era, there is need for cultural architects, custodians and policy makers concerned with cultural growth, revival, reawakening, development, renewal and remediation to educate and lobby for the invaluable aspects of cultures and show how they can be a panacea to the lives of the citizens and the countries at large. The need to discuss and brainstorm the possible benefits of cultures in addressing the states of moral decadence and strengthening the fight against HIVIAIDS has been found to be of central importance. This is because some development pragmatists are increasingly pointing to failure to recognize, appreciate progressive and invaluable aspects of cultures as tools that can strengthen the development of the developing countries.

\section{Methodology}

This article emphasizing on the panacea of cultural rite of passage of virginity testing has used an array of literature from journals, books and assorted materials on cultures; and this researcher's experience as a cultural architect.

\section{Background and Introduction}

This researcher, now a student of culture through his desire to lobby and advocate for cultural integration, cultural innovation, cultural remediation and cultural development, feels that culture needs renewal and revival by the people themselves (Salim, 1992; Serageldin, 1992). People need to look at life positively and use cultural lenses to reflect, introspect and evaluate situations of development (Afolayan, 2004; Kang'ethe, 2013a). People need to be socialized to yearn and desire to reclaim and reposition themselves to benefit from the progressive and rich aspects of cultures such as virginity testing that can give them a sustainable identity, heritage and a space for locating where they are in the continuum of cultural and social development (Afolayan, 2004; Kang'ethe, 2013a). This is because this researcher believes that people without a glorified culture are like slaves without any right of existence, expression, and dignity. This researcher also looks at many aspects of culture which have been abandoned with nostalgia that they get back into community practice and continue shedding their immense social capital with great dividends in people's lives (Kang'ethe, 2013b,c). Perhaps the greatest challenge with the cultural architects, cultural based policy makers and cultural custodians is how to advocate for a paradigm shift that will see people yearning with gusto and nostalgia to reclaim the much glory that their colonial masters demeaned. Their agenda was to break the cultural bond among the Africans so that they can 
be better slaves without a cultural niche that would provide them with strong heritage and identity. They un relentlessly advocated, lobbied for a coup de tat of the African cultures until people internalized and embraced the message that African cultures were naïve, barbaric, demoniac, backward and carried no grain of civilization (Kang'ethe, 2009a). People therefore started embracing and holding as gospel truth the culture of the colonial masters. Since Africa and Europe constitute two geographical locales, the culture of the white man has not adequately matched the expectations of the Africans. While many Africans have maintained some aspects of their cultures, these practices continue to be diluted, degraded by the Africans themselves, with the African elites leading the pack (Afolayan, 2004) to say the least, the elites have relegated the cultures of their ancestors, grandfathers and parents to a second position compared to the culture of the west. It is apparent that it is the elites who have become outright sell out of the African birthright espoused in cultures. This, they need to relinquish if Africans like Japanese are to curve a strong culture integrated into all their aspects of development (Kang'ethe, 2009a, 2013b,c; Salim, 1992; Serageldin, 1992).

Culture needs to be viewed with nostalgia to appreciate some of the African cultural practices that helped societies to maintain their sexual chastity and fought against the state of moral decadence (Kang'ethe, 2013a). It is unfortunate that many years of apartheid and colonialism in South Africa and other countries saw some of these cultural practices falls off from the glory. The colonialists and the imperialists had succeeded in their quest to convince the Africans that their cultural practices were uncultured and antidevelopment (Afolayan, 2004; Kang'ethe 2009a). With HIVIAIDS and moral decadence threatening to wipe away families and wreak the socio-economic and cultural and moral fibers of the countries especially in the developing part of the world, turning to culture and other indigenous ways of discouraging illicit sexual encounters and maintenance of sexual chastity need to be explored (Kang'ethe, 2013a). Perhaps the advice of the World Health Organization for the developing countries to work towards seeking their diverse problems and challenges from their backgrounds fits well with this researcher's assertion of looking for possible indigenous ways of tackling HIVIAIDS and state of moral decadence (WHO, 2002). Since already many countries especially hardest hit by the epidemic have recognized and continue to emphasize on the use of circumcision as a strategy to mitigate the effects of HIVIAIDS (Karl Peltzer et al 2007; Kang'ethe, 2013b), then advocating for the resuscitation of the rite of passage of the virginity testing, in this researchers perspective will hopefully and easily be accepted and internalized. Virginity testing is an ancient cultural tradition which has been carried out in many countries such as Egypt, India and in southern part of Africa among the Zulu people of South Africa and Swazis from Swaziland. Its goal was very succinct, ensuring that women were "sexually clean" or had not engaged in any form of sexual intercourse. It was a cultural practice of ensuring that women would get married as virgins. It was a measure to contain sexual and moral chastity (Kang'ethe, 2013b). In African contexts especially, the tradition died some decades ago as most cultures suffered blows and victimization from the strong wind of modernization, westernization, eurocentrism, civilization, and globalization (Kang'ethe, 2009a).

Virginity testing is also called reed dance. In the southern African context, the culture entails having the young and the adolescents line up, then lie in a row on their backs on grass mats spread out on the ground, then they have to part their legs while older women experienced and respected for their expertise in the evaluative role of virginity testing make their judgment. The judgment is usually not a one woman show, but a collaborative effort where the decision reached attracts some consensus. These women critically and briefly examine each girl's exposed genitals, occasionally parting their labia, to confirm any possible interference or perforation of their hymen. When a girl is confirmed a virgin, it is viewed as a cultural milestone and is celebrated with bliss, dancing, singing and ululations. It was a sign that communities had triumphed in their quest to drive their indigenous paths of achieving the process of giving the societies a reason to maintain sexual chastity as a way of reinforcing and bolstering the fight against sexual promiscuity, sexual holidays and sexual freedom, the vices that are fast sliding the African societies into a state of moral decadence (Afolayan, 2004). When a girl fails, meaning that there was a possibility of her hymen being perforated, she was not embarrassed and had to be taken aside for counselling by the cultural counselors so that she can maintain her secondary virginity and make through to become a marriageable woman who has maintained sexual chastity. she is taken aside so that testers may enquire about the reason for her lost virginity, and teach her how to abstain in the future.

\section{The Panacea of Cultural Rites of Virginity Testing}

\subsection{Resuscitation of Virginity testing a home-grown solution to social vices in South African countries}

Cultural architects and custodians in Africa need to be encouraged to facilitate the return of cultures that had immense social capital that societies today should be using as a panacea to tackle some of the problems that have made most societies be at crossroads (Kang'ethe, 2013b,c). Personalities such as the current South African Zulu King, Goodwill Zwelithini need to be patted on the back for standing solidly steered and focused even when critics of the cultural rite of 
virginity testing are on the increase. This researcher, who is a self styled cultural architect or an advocate of the progressive aspects of cultures throws his hat on such visionary leaders who want African countries to be culturally independent and to adopt indigenous ways of surmounting behavioural oriented problems such as youth behavior, alcoholism and sexually associated crimes such as rape (Kang'ethe, 2013b). Perhaps it is at this juncture that readers be informed that countries that have integrated their cultures with development such as Japan continue to embrace an unshakeable development record. These are countries that were not hoodwinked by the westerners to abandon their cultures and instead adopt a new culture of the westerners, or succumb to the strong forces of westernization, eurocentrism, civilization and globalization (Kang'ethe, 2009a). With the coming back of the virginity testing in South Africa, this is a panacea to tackle the effects of HIVIAIDS and moral decadence. These are serious gaps that the western driven campaigns have not promised to solve. Ironically, the HIVIAIDS campaign especially in Africa has spent a lot of money that could have gone to fighting other important social challenges such as poverty, health and developing the infrastructure. The use of these home grown solutions such as virginity testing has immense advantages in that they do not need a lot of resources. It is just commitment to the culture mores and taboos that benchmark sexual chastity. Perhaps the developed countries need to know that Africans are now ready to use their indigenous knowledge systems (IKS) in tackling many of the ills that the western world has been funding (Kang'ethe, 2011). Perhaps they should come in and offer their goodwill without bringing in their prescriptions as to how to do it. This is taking the route and education of indigenization that has been advocated by indigenization gurus such as Mupedziswa and Osei Hwedie. The two gurus hold that African countries can adequately develop if they abandon western oriented curriculum and ways of conceptualizing development, but use locally available knowledge and resources (Mupedziswa, 2001; Osei Hwedie, 1996; Kang'ethe, 2013d). The resuscitation can also be viewed in terms of responding to the World Health Organizations challenge to the developing countries to work towards looking for the solutions of their problems from their backgrounds. This, in another word, echoes coming with home grown solutions to the problem of moral decadence, sexual permissiveness and promiscuity that societies have slid into (WHO, 2002). The work of the current Zulu King, Goodwill Zwelithini in bringing back the culture of reed dance or virginity testing is urgent and long overdue;

\subsection{Virginity testing an integral component of behavioural change}

One of the ideal roles of cultures in African context has been to shape the behavior, habits, ethics and morals of its citizens, especially to the growing children and the youth (Afolayan, 2004). In many African contexts, there were conventional structures and role differentiation and demarcation as well as specializations indicating as to who was supposed to do what as far as inculcating the morals and ethical disciplines of the adults, the children and the youth were concerened. Pivotally, the elders who were societal role models as far as behavior and discipline was concerned were given special roles to guide, coach and mentor others in various aspects of culture. There were those who were involved in guiding and ensuring people were deeply in track as far as issues of faith and religion were concerned. This for example entailed seeing all the people respect one another. Perhaps this is why the African proverb of "I'am because we are; we are because l'am.." (Kang'ethe \& Rhakudu, 2010) testifies these inextricable relationships between all in the society. Some elders guided and facilitated marriages, reconciliation and managing important cultural ceremonies. These descriptions agree with Kang'ethe's (Kang'ethe, 2009b) description of cultures as mirrors that direct the do's and don'ts of societal members.

Since cultures are usually maintained by norms and thoughts that comply with the cultural expectations, conventions and benchmarks, virginity testing, or popularly known as reed dance is one of the cultural rite of passage in some Southern African countries such as Swaziland, Lesotho and South Africa that ensured that the young girls before they could get married had been shaped by their parents and societies to avoid the illicit behaviours of engaging in sexual overtures before marriage (Kang'ethe, 2013b). This point to the fact that cultures have succinct goals and benchmarks that kept on guiding societies. These benchmarks were important as there were immense societal rewards and appreciation for those who trod safely in the path and track of fulfilling them. Pivotally, the testing represented a serious process and a continuum of behavior change in which the society was an integral participant. This is because the parents and the immediate members of the society had to continually advise and guide the young girl to keep and maintain her virginity to avoid embarrassing herself, her parents and the whole society if she allows any sexual encounter before entering into marriage. Therefore, virginity testing served as a tool of behavior change in that it facilitated the working of cultural taboos and sexual mores that the society had crafted to ensure all the young women will be given into marriage while they were considered "clean" as far as sexual matters were concerned. Perhaps the erosion of such cultures have brought doom to sexual chastity in that the Southern African societies are swimming in a world of sexual permissiveness and promiscuity that make societies prone to sexually transmitted diseases such as HIVIAIDS. The fact that South Africa 
and its neigbours are the most affected in HIVIAIDS in the globe tells of the possible sexual engagement and possible ramifications. The fact that most HIVIAIDS cases in the world are heterosexually driven proves this allegation and norm (Barnett \& Whiteside, 2006; Ndinga-Muvumba \& Pharoah, 2008).

Since virginity testing is a cultural norm of young girls keeping away from sexual encounters, this means also keeping away from forums and practices that can compromise their sexual chastity. This, for example reinforces good morals, good company, lack of engagement in alcohol and many other modern activities that idolizes sexual encounters and promiscuity (Kang'ethe, 2013b). However, at no any time is the resuscitation of the cultural norm of virginity testing in South African region important than that now when sexual mores and taboos appear to have immensely been attacked by the wind of human rights especially pertaining to sexual freedom. Perhaps the laws of South Africa need to be blamed for giving societies much freedom in terms of allowing younger children as young as 12 to have sexual freedom (Republic of South Africa, 1996). This has offered the young an opportunity for sexual experimentation, sexual overtures and pursuit of other illicit behaviours that go with early sexual freedom. This includes partying and drinking etc. With the prevalence of HIVIAIDS threatening to wreak the country's social and economic fibres, then turning to indigenous ways of reverting this trend can be a welcome gesture. Virginity testing, then, can be a panacea that societies need to turn to as a tool of effectuating behavioural change (Kang'ethe, 2013c)

\subsection{Virginity testing forms an integral component of HIV/AIDS campaign}

While the country of Uganda in its HIVIAIDS campaign in the 90's encouraged many of its youth to remain virgin by wooing them with scholarships if they could successfully meet the tests of the time, virginity testing in the Southern part of the African region would be a norm of strengthening such an exercise. With knowledge that over $90 \%$ of the HIVIAIDS transmission is through sexual intercourse, and the fact that South Africa is the country with the highest number of people living with HIVIAIDS, while its neigbours such as Swaziland, Lesotho and Zimbabwe are also immensely affected, then all measures that can stem down possibilities of sexual overture needs to be encouraged (Ndinga-Muvumba, 2008; Ramphele, 2008; Barnett \& Whiteside, 2006). Perhaps the battle to bring back the culture of reed dance is likely to be accepted as people of South Africa are increasingly accepting the culture of male circumcision as a strategy to mitigate the effects of HIVIAIDS (Kang'ethe, 2013b; Karl Peltzer et al., 2007). The campaign for male circumcision, though a global one has been accepted in many African countries after empirical research proved that males who are circumcised are $60 \%$ resilient to HIVIAIDS. As Southern African countries continue to gather momentum in the male circumcision campaign in order to stem down the tide of the HIVIAIDS transmission and infections (Karl peltzer et al., 2007; Kang'ethe, 2013b), then the resuscitation of virginity testing is even a stronger intervention and a huge asset to the HIVIAIDS campaign

\section{Stumbling Blocks Lying Along The Rescustation of Virginity Testing}

The western world countries through imperialism, capitalism and colonialism appeared to have won the battle against weakening, diluting and extinguishing African cultures (Afolayan, 2004). This is possibly because most African cultures are being demeaned and weakened by the African elites who should know well the value of cultures. There is therefore the need for people to curve their own cultural identity and therefore leave a legacy and heritage for the coming generations (Salim, 1992; Serageldin, 1992). While many western world countries such as Spain and Japan have strong cultural identity, heritage and have preserved their cultural artefacts, arts and history, as well as mounted huge monuments to mark their countries' historical milestones, Africans appear to be awakening to do the same, but only at a snail's pace. They had been brainwashed to view their culture as a dispensable one that if drained away could bear forth a new beneficial culture of its erstwhile colonial masters. This saw invaluable cultures such as virginity testing in the Southern African countries die a natural death (Kang'ethe 2009a; Afolayan, 2004).

It is the challenge of cultural architects such as this writer to rise to the challenge and advocate, lobby and educate the Africans of the need to reclaim and reposition themselves ready to revert to some of the progressive aspects of cultures that may form home grown solution to the myriad social challenges the continent is facing (Kang'ethe, 2013a). The elites need to take the issue seriously and accept to undergo a paradigm shift and start seeing development also from the cultural lenses. Perhaps this is one of the latent ways that can make the continent assume a higher pace in development just like other continents such as Asia. Asia, especially some countries of it were lagging behind in development a few decades ago, but as of now, are moving at a recommendable pace. However, it needs not be lost that many of these Asian countries have respected, or have integrated their cultures into development (Salim, 1992; Seragelden, 1992). 
As the campaign and cultural architects draws their dagger in readiness for the battle to resuscitate the culture of reed dance, the very same western world imperialists and colonialists have come in through human rights messaging indicating that virginity testing constitutes a human rights denial and violation. This has seen many local NGOs being funded to advocate and lobby against the exercise. The unfortunate state of scenario is that the government forces appears to have succumbed to the wind and whims of the western world human rights crusade that cultures such as virginity testing pose human rights violation. This researcher thinks that it is time African people choose for themselves what they think can work for themselves. While human rights need to be respected and implemented where they have huge dividends and an improvement of human lives, it's time to conduct serious cost benefit analysis (CBA) and separate the "wheat from the chaff". This researcher authoritatively consider the culture of virginity testing a panacea especially this time that many African countries are experiencing serious challenges of moral decadence and the prevalence of HIVIAIDS. It is this researcher's contention, therefore, that virginity testing should be viewed by all through cultural lenses in terms of cultural rights which have a pivotal place in the continuum of human rights. This researcher, therefore, calls for any Dick and Harry to support the progressive aspects of cultures such as virginity testing. Its time that African countries such as South Africa and Swaziland that have the experience of virginity testing share the glory with other countries ; or export the trade to other African countries through the goodwill of cultural pollination.

\section{Conclusion}

Importantly, Africans need to revert, reinvent and reclaim their cultural lost glory and move to identify their immense cultural social capital embedded in them. They should carry out a cost benefit analysis to separate the progressive from the retrogressive aspects of culture. In this researcher's perspective and contention, the culture of virginity testing, also so called reed dance need to be resuscitated to facilitate and bolster the fight against HIVIAIDS and moral decadence. The governments especially of the South Africa region, through the support of their ministries of culture need to fund many of the campaigns to convince the people of the value of the culture as far as fighting some of the social vices such as HIVIAIDS are concerned. The cultural architects and custodians who believe in the panacea of many of the cultural practices need not relent in writing, advocating and lobbying for a cultural paradigm shift among the countries such as South Africa that stands to benefit from the practice.

\section{Acknowledgements}

The author acknowledges motivation and tapping of immense wisdom on cultural knowledge on virginity testing from Festus Kayundi, Senior Lecturer, Department of Library Sciences, University of Fort Hare.

\section{References}

Afolayan, F. ( 2004). Culture and Customs of South Africa. Westport, Connecticut: Greenwood Press

Barnett, T. \& Whiteside, A. ( 2002). AIDS in the Twenty-First Century. Disease and Globalization. Hampshire: Palgrave Macmillan.

Kang'ethe, S. M. ( 2009a). "Inadequate male involvement in health issues: The cause of gender skewed HIV and AIDS situations in Botswana". In: Maundeni T, Osei Hwedie B.Z,

Mukaamambo E. and Ntseane (eds). Male involvement in Sexual and Reproductive Health. Prevention of Violence and HIV/AIDS in Botswana: 1-28.

Kang'ethe, S.M. (2009b). Traditional healers as caregivers to HIVIAID patients. Sahara Journal. Vol. 6 (2). September, 2009. Pp.83-91.

Kang'ethe, S.M \& Rhakudu, M. (2010). Religious Education book for form 2. Heinemann Publishers, Gaborone.

Kang'ethe, S.M.( 2011). Evidences of indigenous knowledge systems driving care giving in care programmes in Botswana. Fort Hare Papers. Vol 18, 2011. Pp 5-15.

Kang'ethe, S.M. ( 2013a). Repositioning, Reclaiming and Rejuvenating the Niche of Traditional Practitioners in the face of Modernization in selected African Countries. In the Press of Studies on Ethno-Medicine, India

Kang'ethe, S.M. (2013b). The panacea and perfidy of culture as a platform of behavior change with examples from Botswana and South Africa. In the press of Social Work Practitioner, University of Johannesburg,

Kang'ethe, S. M. (2013c). The panacea and perfidy of cultural rites of circumcision in African countries: Examples from Kenya, Botswana and South Africa. EASSRR Journal, Vol. xxix, no 1: 107-123.

Kang'ethe, S. M. ( 2013d). Exploring social work gaps with examples from South Africa and Botswana: In the press of Journal of Social Sciences.

Mupedziswa, R. (2001). The quest for relevance. Towards a conceptual model of developmental social work education and training in Africa. International Social Work. July 2001.Vol 44. No 3: 285-300.

Ndinga-Muvumba, A. \& Pharoah, R. ( 2008). HIV/AIDS and society in South Africa. University of Kwazulu Natal Press 
Osei-Hwedie, K. (1996). The indigenisation of Social Work Practice and Education in Africa: The Dilemma of Theory and Method. Social Work/Maatskaplike Work, 32 (3): 215-25.

Peltzer, K, Niang, C.I., Muula, A. S., Bowa, K., Okeke, L. et al. (2007). Male Circumcision, gender, and HIV prevention in sub-Saharan Africa: A (social science) research agenda. Journal of Social Aspects of HIVIAIDS, 4(3), 658-67.

Ramphele, M. (2008). Laying ghosts to Rest. Dilemmas of the Transformations in South Africa. Capetown: Tafelberg

RSA (Republic of South Africa) (1996). Constitution of the Republic of South Africa No 108 of 1996. South Africa. Capetown. Government Gazette. Avaialbale at http://www.info.gov.za/documents/constitution/1996/a108-96.pdf.Accessed on 23/06/2011

Salim, S.A (1992). Opening Remarks in Serageldin I and Taboroff J (1992). Culture and Development in Africa. Proceedings of an international Conference held at The World bank, Washington, DC. April 2 and 31992

Serageldin, I(1992). Introduction in Serageldin I and Taboroff J (1992). Culture and Development in Africa. Proceedings of an international Conference held at The World bank,Washington, DC. April 2 and 31992

WHO ( 2002). Community Home -Based Care in Resource- Limited Settings. A Framework for Action. 20 Avenue Appia, 1221 Geneva 27, Switzerland; 2002. 